\title{
Guidelines for penile plethysmography (PPG) usage
}

I should like to draw to the attention of psychiatric colleagues the guidelines for the use of PPG assessments. These were produced by a working group of forensic psychologists drawn from the special hospitals, NHS regional and district forensic services, the Prison Department and youth treatment centres.

The background to the development of the guidelines was the marked growth in the use of PPG assessments in various treatment programmes for sex offenders, particularly in the Prison Department, and it was felt important to offer proactive guidance to professionals undertaking what is both a complex and potentially controversial type of assessment. The guidelines are intended to inform good practice while allowing for the exercise of professional judgement in particular situations. They have been approved and endorsed by the Professional Affairs Board of the British Psychological Society, and relate to a wider code of professional conduct for psychologists.

JULIAN Fuller, Consultant Clinical Psychologist, Forensic Psychiatric Service, Butler Clinic, Langdon Hospital, Dawlish, Devon EX7 ONR and Chairperson, MultiAgency Working Group of Forensic Psychologists

These brief guidelines are intended to inform good practice in penile plethysmograph (PPG) assessment, while allowing for the exercise of professional judgement in particular situations. They should be read in conjunction with existing guidelines on professional conduct produced by the British Psychological Society and the references that follow them.

(1) Responsibility for the supervision of the PPG assessment should rest with a psychologist who is eligible to be registered as a Chartered Psychologist. The psychologist should have up-to-date knowledge of relevant practice, legal issues and literature. (See reference list).

(2) Staff participating in this work at any level should be adequately briefed and have the option not to be involved should they find the procedure or material distressing.

(3) The PPG test should be carried out only in the context of an appropriate range of other assessment and treatment procedures or in the course of research that has been professionally and ethically approved by the relevant body.

(4) Selection of the stimuli should take into account ethical consideration of how the material was produced or obtained, e.g. if it was under abusive circumstances.

(5) Selection of PPG stimuli (content and mode of presentation) should take into account an appropriate balance between obtaining the best possible assessment and risk of exposing the subject to material which may be therapeutically counter-productive if it is outside their own suspected or known experience.

(6) The psychologist should brief the subject on the purpose and procedures involved in PPG assessment including possible results and their interpretation. He or she should explain limits of confidentiality and likely consequences of participation, non-participation and withdrawal and check that the subject has understood.

(7) Debriefing should be carried out at the end of each assessment. This should include consideration of the impact of the assessment on the client and the need for support and advice.

(8) A record that the subject has been properly briefed and debriefed should be kept when appropriate.

(9) Stimuli material for PPG assessment should be kept secure and access limited to those using it for professional purposes. 
(10) Assessment should only be carried out in appropriate physical conditions with due regards to the standards of safety, privacy, comfort and hyglene recommended in recent publications such as Coleman \& Dwyer (1990) or ATSA (1992).

\section{References and further reading}

ASSOCLATION FOR THE TREATMENT OF SEXUAL ABUSERS (ATSA) (1992) Guidelines for the use of the penile plethysmograph. Unpublished.

COLEMAN, E. \& DWYER, M. (1990) Proposed standards of care for the treatment of adult sex offenders. Journal of Offender Rehabilitation, 16. 93-106.

Fedora, O., Reddon, J. R., MuRRISON, J. W., Fedora, S. K., PASCOE, H. \& Yeudall, L. T. (1992) Sadism and other pariphilias in normal and aggresstve sex offenders. Archives of Sexual Behaviour, 21, 1-15.
LAUNAY, G. (1994) The phallometric assessment of sex offenders: some professional and research issues. Criminal Behaviour \& Mental Health, 4, 48-70.

MURPHY. W. D., HAYNeS, M. R. \& MORLEY, P. J. (1991) Assessment of adult sexual interest. In Clinical Approaches to Sex Offenders and their Victims. (eds C. R. Hollin \& K. Howells). London: John Wiley.

PItHERS, W. D. \& LAws, D. R. (1988) The penille plethysmograph. In A Practitioner's Guide to Treating the Incarcerated Male Sex Offender (eds B. K. Schartz \& H. R. Cellini). Washington DC: US Department of Justice, National Institute of Corrections.

Rosen, R. C. \& HALL, K. S. K. (1992) Behavioural treatment approaches for offenders and victims. In The Sexual Abuse of Children: Clinical Issues, Volume 2. (eds W. O'Donohue \& J. H. Greer). Hove: Lawrence Erlbaum Associates.

SCHNUTEN, P. G. W. \& SimON, W. T. (1992) Validity of phallometric measures with sex offenders: comments on the Quinsey. Laws and Hall debate. Journal of Consulting and Clinical Psychology, 60, 812-814.

Simon, W. T. \& Schnuten, P. G. W. (1991). Plethysmograph in the assessment and treatment of sexual deviance: an overview. Archives of Sexalal Behaviour, 20, 75-91. 